\title{
Gambaran Tekanan Darah pada Pasien Sindrom Koroner Akut di RS Khusus Jantung Sumatera Barat Tahun 2011-2012
}

\author{
Meidiza Ariandiny, Afriwardi, Masrul Syafri
}

\begin{abstract}
Abstrak
Penyakit jantung koroner merupakan penyakit degeneratif dengan permasalahan yang serius karena prevalensinya yang terus meningkat. Keadaan yang mengkhawatirkan dari penyakit jantung koroner adalah pada fase akut atau disebut dengan sindrom koroner akut. Salah satu faktor yang menyebabkan terjadinya sindrom koroner akut adalah tekanan darah yang tinggi yang mengakibatkan pecahnya plak aterosklerotik. Penelitian bertujuan untuk mengetahui gambaran tekanan darah pada pasien sindrom koroner akut di RS Khusus Jantung, Sumatera Barat dan mengetahui jenis hipertensi yang terjadi. Penelitian dilakukan dengan mengambil data sekunder yaitu data tekanan darah awal masuk rumah sakit pada pasien sindrom koroner akut di RS Khusus Jantung, Sumatera Barat pada bulan Maret-April 2013. Penelitian ini merupakan studi deskriptif observasional dengan total sampling. Analisis data yang dilakukan adalah analisis univariat. Hasil penelitian dari 145 data ditemukan bahwa hipertensi (tekanan darah tinggi) sebanyak 88 pasien (61\%), prehipertensi sebanyak 33 pasien (23\%), dan normotensi sebanyak 24 pasien (16\%), dengan jenis hipertensi yaitu hipertensi kombinasi sebanyak 53 pasien (60\%), hipertensi sistolik sebanyak 20 pasien (23\%) dan hipertensi diastolik sebanyak 15 pasien (17\%). Kelompok usia yang terbanyak yaitu usia 46-55 tahun (30\%) diikuti kelompok usia 66-75 tahun (25\%), 56-65 tahun (24\%), >76 tahun (10\%), 36-45 tahun (0,8\%), dan < 35 tahun $(0,2 \%)$ dengan jenis kelamin laki-laki sebesar $74 \%$ dan perempuan sebesar $26 \%$. Kesimpulan dari hasil penelitian adalah gambaran tekanan darah pada pasien sindrom koroner akut yang terbanyak yaitu hipertensi dengan jenis hipertensi kombinasi. Kelompok usia terbanyak yaitu usia 46-55 tahun dengan jenis kelamin laki-laki.
\end{abstract}

Kata kunci: tekanan darah, hipertensi, sindrom koroner akut

\begin{abstract}
Coronary heart disease is a degenerative disease. It becomes serious because the prevalence continues increase. The worst condition is the acute phase which is called acute coronary syndrome. The high blood pressure is one of the risk factors of acute coronary syndrome because it lead atherosclerotic plaques ruptured. This research aims is to describe the blood pressure and the type of hypertension in patients with acute coronary syndromes in The Heart Hospital, West Sumatera. This research took the secondary data of admission blood pressure in patients hospitalized with acute coronary syndrome in The Heart Hospital, West Sumatera, March - April 2013. This research is an observational descriptive study with a total sampling. Data analysis was performed univariate analysis. The results of 145 data were 88 patients (61\%) had hypertension (high blood pressure), 33 patients (23\%) were prehypertension, and 24 were normotensive (16\%). The type of hypertension were 53 patients with combination hypertension (60\%), 20 patients with systolic hypertension (23\%) and 15 patients with diastolic hypertension (17\%). Based on the age classification of hypertension, found that $46-55$ years were $30 \%, 66-75$ years were $25 \%$, 56-65 years were $24 \%$, > 76 years were $10 \%, 36-45$ years were $0.8 \%$, and $<35$ years were $0.2 \%$. based on gender classification of hypertension found that male gender were $74 \%$ and women were $26 \%$. The conclusion of this research find that the largest blood pressure in patients with acute coronary syndromes is hypertension, the largest type of hypertension is combination hypertension, the largest age classification is 46-55 years, and the largest gender classification is male.
\end{abstract}

Keywords:blood pressure, hypertension, acute coronary syndrome

Affiliasi penulis : Fakultas Kedokteran Universitas Andalas Korespondensi :Meidiza Ariandiny, Email: ameidiza@yahoo.co.id, Telp: 082389038002

\section{PENDAHULUAN}

Penyakit jantung koroner adalah salah satu penyakit degeneratif yang menjadi masalah serius di dunia karena prevalensinya yang terus meningkat. Penyakit jantung koroner ini disebabkan oleh manifestasi aterosklerosis di pembuluh darah koroner dan banyak menyerang individu-individu di usia produktif. $^{.}$Di Amerika Serikat, pada tahun 1998, penyakit jantung koroner merupakan penyebab kematian utama dengan persentase sebesar $48 \%$, dan pada tahun 2004 didapatkan angka kematian akibat penyakit jantung koroner di Amerika Serikat sebesar
450.000 kematian, sedangkan di Indonesia, berdasarkan hasil Survei Kesehatan Nasional tahun 2001 didapatkan 3 dari 1000 penduduk Indonesia menderita penyakit jantung koroner. ${ }^{1-3}$ Penyakit Jantung Koroner dapat terjadi secara kronis maupun akut. Hal yang menakutkan bagi sebagian orang adalah penyakit jantung koroner akut atau lebih dikenal dengan Sindrom Koroner Akut. Sindrom Koroner Akut adalah ketidak mampuan jantung akut akibat suplai darah yang mengandung oksigen ke jantung tidak adekuat. Hal ini disebabkan oleh peningkatan kebutuhan oksigen, transpor oksigen darah berkurang dan yang paling sering yaitu pengurangan aliran koroner karena penyempitan atau obstruksi arteri yang disebabkan oleh aterosklerosis. Manifestasi dari sindrom koroner akut dapat berupa 
angina tak stabil, infark miokard akut tanpa elevasi segmen ST, infark miokard akut dengan elevasi segmen ST dan juga dapat menyebabkan kematian jantung yang mendadak. ${ }^{4}$ Pada tahun 2006, hampir 1,4 juta penduduk Amerika didiagnosis menderita sindrom koroner akut meliputi 537.000 dengan angina tak stabil dan 810.000 dengan infark miokard akut. ${ }^{5}$

Sindrom Koroner Akut disebabkan oleh beberapa faktor risiko. Salah satu faktor risiko utama yang menyebabkan terjadinya sindrom koroner akut adalah tekanan darah yang tinggi (hipertensi). Menurut JNC VII 2004, hipertensi merupakan hasil pengukuran tekanan darah sistolik $\geq 140 \mathrm{mmHg}$ atau tekanan darah diastolik $\geq 90 \mathrm{mmHg}$. Peningkatan tekanan darah $20 / 10 \mathrm{~mm} H g$ dapat meningkatkan risiko penyakit jantung sebesar dua kali lipat dan meningkatkan risiko kematian akibat sindrom koroner akut sebesar dua kali lipat. ${ }^{6,7}$ Hipertensi merupakan salah satu pencetus dari aterotrombosis. Hipertensi dapat menyebabkan sindrom koroner akut dengan beberapa mekanisme, diantaranya dengan menyebabkan hipertrofi jantung, disfungsi endotel atau gangguan pada sistem reninangiotensin. $^{8}$

Kejadian hipertensi mengalami peningkatan seiring dengan perubahan pola hidup di masyarakat dan peningkatan risiko seiring pertambahan usia. Hal ini mengakibatkan prevalensi hipertensi tidak terkontrol di dunia mengalami peningkatan dari 600 juta orang tahun 1980 menjadi 1 milyar di tahun 2008 dengan angka kejadian pada pria lebih tinggi daripada perempuan. $^{6}$

Hipertensi merupakan penyakit multifaktorial yang diakibatkan oleh beberapa faktor risiko Berdasarkan etiologinya, hipertensi dapat dibedakan menjadi hipertensi essensial atau hipertensi primer dan hipertensi sekunder. Hipertensi essensial adalah hipertensi yang tidak diketahui penyebabnya dan merupakan $95 \%$ penyebab dari hipertensi dan $5 \%$ sisanya merupakan hipertensi sekunder. ${ }^{9}$

Hipertensi juga dapat dibagi menjadi hipertensi sistolik pada usia yang lebih tua ( $>60$ tahun) dan hipertensi diastolik pada usia 30-50 tahun. ${ }^{10}$ Hipertensi sistolik (terisolasi) adalah tekanan darah sistolik $\geq 140 \mathrm{mmHg}$ dan tekanan darah diastolik $<90$ $\mathrm{mmHg}$. Tekanan darah sistolik merupakan parameter untuk stratifikasi risiko penyakit jantung pada usia yang lebih tua. Prevalensi hipertensi sistolik (terisolasi) meningkat pada usia > 60 tahun. $^{11}$ Sedangkan, hipertensi diastolik (terisolasi) merupakan peningkatan tekanan darah diastolik $>90 \mathrm{mmHg}$ dengan tekanan sistolik normal. Biasanya, hipertensi diastolik terjadi pada pria dengan berat badan yang berlebih dan sindrom metabolik. ${ }^{10}$

Di Indonesia, berdasarkan hasil pengukuran darah dari Riset Kesehatan Dasar 2007 diperoleh prevalensi hipertensi pada penduduk usia 18 tahun keatas di Indonesia adalah sebesar $31,7 \%{ }^{12}$ Sumatera Barat merupakan salah satu provinsi yang memiliki prevalensi hipertensi yang cukup tinggi. Pada tahun 2007, prevalensi hipertensi di Sumatera Barat sebesar 26,3\%. ${ }^{12}$ Sementara itu di Kota Padang, diketahui bahwa hipertensi menduduki peringkat lima untuk penyakit terbanyak di kota Padang dengan jumlah kasus sebanyak 36.456 kasus setelah ISPA, gastritis, penyakit sendi dan rematik serta penyakit kulit. $^{13}$

Pada tahun 2012, Ali dkk, melaporkan bahwa $49,4 \%$ pasien sindrom koroner akut menderita hipertensi. Berdasarkan data observasional didapatkan bahwa lebih dari 1 juta orang diindikasikan meninggal karena sindrom koroner akut dengan peningkatan tekanan darah yang progresif. ${ }^{14} \mathrm{Hal}$ inilah yang mendorong penulis untuk melihat bagaimana gambaran tekanan darah pasien sindrom koroner akut di Sumatera Barat. Tujuan penelitian ini adalah untuk mengetahui gambaran tekanan darah pada pasien sindrom koroner akut ketika masuk RS Khusus Jantung Sumatera Barat tahun 2011-2012.

\section{METODE}

Desain penelitian adalah penelitian dengan jenis observasional deskriptif dengan mengambil data pada kejadian masa lalu. Populasi penelitian adalah data rekam medik pasien sindrom koroner akut di RS Khusus Jantung Sumatera Barat tahun 2011-2012 dengan teknik pengambilan Total Sampling sebanyak 145 data. Peneliitian dilaksanakan dari bulan Maret 2013-April 2013.

Variabel dependen penelitian adalah sindrom koroner akut yaitu penyakit jantung koroner saat akut, dinyatakan mengalami angina pectoris tak stabil atau infark oleh dokter spesialis jantung berdasarkan manifestasi klinis dan elektrokardiografi (EKG) dan pada penyadapan jantung dijumpai penyempitan koroner yang bermakna (> 50\%) dan atau terdapat riwayat revaskularisasi coroner dengan cara CABG atau $\mathrm{PCl}$. Data didapatkan dengan mengidentifikasi data rekam medik dengan alat ukur checklist. Hasil ukur yaitu (1) ya (jika memenuhi definisi operasional), (2) tidak (tidak memenuhi definisi operasional). Variabel independen penelitian adalah tekanan darah yaitu daya yang dihasilkan oleh darah terhadap setiap satuan luas dinding pembuluh yang dinyatakan dalam milimeter air raksa $(\mathrm{mmHg})$. Data didapatkan dari mengidentifikasi data rekam medik dengan alat ukur yaitu checklist tekanan darah ketika masuk rumah sakit pada rekam medik. Hasil Ukur yaitu (1) normotensi (tekanan darah sistolik $<120 \mathrm{mmHg}$ dan tekanan darah diastolik $<80 \mathrm{mmHg}$ ), (2) prehipertensi (tekanan darah sistolik $120-139 \mathrm{mmHg}$ atau tekanan darah diastolik $80-89 \mathrm{mmHg}$ ), (3) hipertensi (tekanan darah sistolik $\geq 140 \mathrm{mmHg}$ dan/atau tekanan darah diastolik $\geq 90 \mathrm{mmHg}$ ), (4) hipertensi sistolik (tekanan darah sistolik $\geq 140 \mathrm{mmHg}$ dan tekanan darah diastolik < $90 \mathrm{~mm} \mathrm{Hg}$ ), (5) hipertensi diastolik terisolasi (tekanan darah sistolik $<140 \mathrm{mmHg}$ dan tekanan darah diastolik $\geq 90 \mathrm{mmHg}$ ), (6) hipertensi kombinasi (tekanan darah sistolik $\geq 140 \mathrm{mmHg}$ dan tekanan darah diastolik $\geq 90 \mathrm{mmHg}$ ).

Langkah-langkah pengolahan data yang dilakukan yaitu memeriksa kelengkapan dan kejelasan data, memberikan kode pada setiap data yang terkumpul, menyusun dan menghitung data hasil pengkodean untuk disajikan dalam tabel, memeriksa kembali data yang telah dimasukkan untuk memastikan data bersih dari kesalahan. Analisa data yang dilakukan yaitu analisis univariat. Analisis univariat digunakan untuk menggambarkan distribusi frekuensi setiap variabel dalam bentuk persentase.

\section{HASIL}

Pada penelitian ini didapatkan populasi 148 data rekam medik pasien Sindrom Koroner Akut (SKA) di RS Khusus Jantung, Sumatera Barat dengan 145 data rekam medik yang memenuhi kriteria penelitian. Hasil penelitian dapat dijelaskan sebagai berikut: 


\section{Tekanan Darah}

Tabel 1. Klasifikasi tekanan darah pada pasien SKA

\begin{tabular}{lcc}
\hline Tekanan darah & Frekuensi & $\%$ \\
\hline normotensi & 24 & 16 \\
prehipertensi & 33 & 23 \\
hipertensi & 88 & 61 \\
\hline Jumlah & 145 & 100 \\
\hline
\end{tabular}

Pada tabel 1 dilihat bahwa dari 145 data pasien SKA didapatkan klasifikasi tekanan darah terbanyak adalah hipertensi sebanyak 88 orang $(60 \%)$.

\section{Jenis Hipertensi}

Tabel 2. Jenis hipertensi pada pasien SKA

\begin{tabular}{lcc}
\hline Jenis hipertensi & Frekuensi & $\%$ \\
\hline Hipertensi diastolik & 15 & 17 \\
Hipertensi sistolik & 20 & 23 \\
Hipertensi kombinasi & 53 & 60 \\
\hline Jumlah & 88 & 100 \\
\hline
\end{tabular}

Pada tabel 2 dilihat bahwa dari 88 data pasien SKA dengan hipertensi didapatkan jenis hipertensi terbanyak adalah hipertensi kombinasi sebanyak 53 orang $(60 \%)$.

3. Umur

Tabel 3. Distribusi frekuensi SKA dengan hipertens berdasarkan umur

\begin{tabular}{lcc}
\hline Umur (tahun) & Frekuensi & $\%$ \\
\hline$\leq 35$ & 2 & 0,2 \\
$36-45$ & 7 & 0,8 \\
$46-55$ & 26 & 30 \\
$56-65$ & 21 & 24 \\
$66-75$ & 22 & 25 \\
$\geq 76$ & 10 & 1 \\
\hline Jumlah & 88 & 100 \\
\hline
\end{tabular}

Pada tabel 3 dilihat bahwa dari 88 data pasien SKA dengan hipertensi didapatkan kelompok umur terbanyak adalah 46-55 tahun yaitu sebanyak 26 orang $(30 \%)$ dan terkecil adalah $\leq 35$ tahun sebanyak 2 orang $(0,2 \%)$.

4. Jenis Kelamin

Tabel 4. Distribusi frekuensi SKA dengan hipertensi berdasarkan jenis kelamin

\begin{tabular}{lcc}
\hline $\begin{array}{l}\text { Jenis } \\
\text { Kelamin }\end{array}$ & Frekuensi & $\%$ \\
\hline Laki-laki & 65 & 74 \\
Perempuan & 23 & 26 \\
\hline Jumlah & 88 & 100 \\
\hline
\end{tabular}

Pada tabel 4 dilihat bahwa dari 88 data pasien SKA dengan hipertensi didapatkan jenis kelamin terbanyak adalah laki-laki sebanyak 74 orang (74\%).

\section{PEMBAHASAN}

\section{Tekanan Darah}

Tekanan darah yang tinggi dan menetap akan menimbulkan trauma langsung terhadap dinding pembuluh darah arteri koronaria, sehingga memudahkan terjadinya aterosklerosis koroner. Hal ini menyebabkan angina pektoris, insufisiensi koroner dan infark miokard lebih sering terjadi pada penderita hipertensi dibandingkan orang normal. ${ }^{15}$

Penelitian Ali, dkk(2012) didapatkan sebanyak $47,7 \%$ pasien sindrom koroner akut menderita hipertensi. Pasien sindrom koroner akut yang menderita hipertensi sebagian besar berjenis kelamin laki-laki dan berusia lebih tua dibandingkan dengan pasien tanpa hipertensi. ${ }^{14}$ Selain itu, penelitian yang dilakukan oleh Abidin di RS Wahidin Sudirohusodo Makassar (2008) diperoleh pasien penyakit jantung koroner yang menderita hipertensi sebanyak $63,6 \%{ }^{16}$

Hal ini sesuai dengan hasil penelitian pada tabel 1 dilihat bahwa dari 145 data rekam medik pasien sindrom koroner akut didapatkan klasifikasi tekanan darah terbanyak adalah hipertensi sebanyak 88 orang $(60 \%)$.

Berdasarkan penelitian Van Den Hoogen, $d k k$ (2000) pada pasien sindrom koroner akut selama 25 tahun didapatkan bahwa hipertensi merupakan salah satu faktor risiko yang signifikan untuk angka kematian pada pasien sindrom koroner akut. Setiap kenaikan tekanan darah sistolik sebesar $10 \mathrm{mmHg}$ atau kenaikan tekanan diastolik sebesar $5 \mathrm{mmHg}$ dapat meningkatkan risiko relatif kematian sindrom koroner akut, selain itu penurunan tekanan darah pada penderita hipertensi sebesar $5 \mathrm{mmHg}$ akan menurunkan risiko infark miokard sebesar $15 \%{ }^{17,18}$

\section{Jenis Hipertensi}

Penelitian Sugiharto (2007) didapatkan bahwa faktor-faktor yang terbukti sebagai faktor risiko hipertensi adalah umur, riwayat keluarga, konsumsi asin, sering konsumsi lemak jenuh, penggunaan jelantah, tidak biasa olah raga, olah raga tidak ideal, obesitas dan penggunaan pil KB 12 tahun berturutturut. Penelitian mengenai faktor risiko juga dilakukan oleh Irza (2010) yang didapatkan bahwa faktor risiko utama hipertensi adalah usia. ${ }^{19,20}$

Penelitian Framingham mendapatkan bahwa hipertensi sistolik merupakan faktor pencetus terjadinya angina pektoris dan infark miokard. Selain itu, tekanan darah diastolik $90-100 \mathrm{mmHg}$ akan meningkatkan risiko infark miokard sebesar $2 x$ lipat dan apabila hipertensi sistolik dan hipertensi diastolik terjadi bersamaan akan menunjukkan risiko yang lebih besar. $^{15}$

Pada tabel 2 dapat dilihat bahwa jenis hipertensi terbanyak dari 88 data rekam medik pasien sindrom koroner akut adalah hipertensikombinasi yaitu sebanyak 53 pasien (60\%), diikuti hipertensi sistolik sebanyak 20 orang (23\%) dan hipertensi diastolik sebanyak 15 orang (17\%).

Umumnya tekanan sistolik akan meningkat sejalan dengan bertambahnya usia sebaliknya, tekanan darah diastolik akan meningkat sampai usia 55 tahun, dan kemudian akan menurun sejalan dengan pengerasan (kekakuan) dinding pembuluh darah arteri yang semakin meningkat. ${ }^{21}$

\section{Umu}

Dengan bertambahnya usia, semakin meningkatnya prevalensi kejadian hipertensi. Hal ini disebabkan karena arteri kehilangan keelastisitasannya seiring bertambahnya usia. ${ }^{19} \mathrm{Di}$ dalam penelitiannya, Irza menyatakan bahwa kejadian hipertensi meningkat pada kelompok usia $\geq 40$ tahun. $^{20}$

Demikian juga dengan angka kejadian penyakit jantung koroner yang juga mengalami peningkatan seiring dengan pertambahan usia dengan 
angka kematian terbanyak pada laki-laki dengan usia 45-59 tahun. $^{22}$

Pada hasil penelitian Ismantri di RS Binawaluya, didapatkan $58,6 \%$ pasien penyakit jantungkoroner adalah yang berumur 45-59 tahun, diikuti kelompok usia $\geq 60$ tahun dan terakhir kelompok usia $\leq 44$ tahun. 22

$\mathrm{Hal}$ ini sejalan dengan hasil penelitian seperti terlihat pada tabel 3 bahwa dari 88 data rekam medik pasien sindrom koroner akut dengan hipertensi didapatkan kelompok umur terbanyak adalah 46-55 tahun sebanyak 26 orang (30\%).

\section{Jenis Kelamin}

Penelitian Ratna dkk (2012) menyatakan bahwa penderita penyakit jantung koroner di puskesmas Gamping 2 Sleman terbanyak adalah lakilaki dengan persentase $83,3 \%$. Hal ini disebabkan karena sebelum memasuki masa menopause, wanita memiliki hormon estrogen yang merupakan protektan terhadap kejadian aterosklerosis. ${ }^{22}$

Hal ini sesuai dengan hasil penelitian pada tabel 4 dapat dilihat bahwa dari 88 data rekam medik pasien sindrom koroner akut dengan hipertensi didapatkan jenis kelamin terbanyak adalah laki-laki 65 orang (74\%).

Pada penelitian yang dilakukan Ismantri didapatkan bahwa penderita penyakit jantung koroner terbanyak adalah laki-laki $(75,9 \%)$. Hal ini diperkuat dengan hasil penelitian oleh Abidin di RS Wahidin Sudirohusodo Makassar tentang penyakit jantung koroner, yaitu prevalensi laki-laki sebanyak $75 \%$. ${ }^{16,22}$

\section{KESIMPULAN}

Berdasarkan penelitian tentang gambaran tekanan darah pada pasien Sindrom Koroner Akut di RS Khusus Jantung, Sumatera Barat terhadap 145 populasi disimpulkan bahwa :

1. Sebagian besar pasien SKA menderita hipertensi (tekanan darah sistolik $\geq 140 \mathrm{mmHg}$ dan/atau tekanan darah diastolik $>90 \mathrm{mmHg}$ )

2. Sebagian besar pasien SKA dengan hipertensi kombinasi.

3. Sebagian besar pasien SKA dengan hipertensi berumur 46-55 tahun.

4. Sebagian besar pasien SKA dengan hipertensi berjenis kelamin laki-laki.

5. Jumlah pasien SKA pada tahun 2011-2012 adalah sebanyak 148 pasien.

\section{DAFTAR PUSTAKA}

1. Sumiati. Penanganan stres pada penyakit jantung koroner. Jakarta: CV. Trans Info Media; 2010.

2. Brown CT. Penyakit aterosklerotik koroner. Dalam: Price SA, Wilson LM, editor. Patofisiologi konsep klinik proses-proses penyakit vol.1. Edisi6. Jakarta: EGC; 2006. hlm. 576.

3. Capewell S, Hayes DK, Ford ES, Critchley JA, Croft JB, Greenlund KJ, et al. Life-years gained among US adults from modern treatments and changes in the prevalence 6 coronary heart disease risk factor between 1980 and 2000. American Journal of Epidemiology. 2009. (diunduh 26 Maret 2013). Tersedia dari: URL: HYPERLINK http://www.ncbi.nlm.nih.gov/pubmed/19541856.

4. Dorland WAN. Kamus kedokteran Dorland. Edisi ke-29. Jakarta: EGC; 2002.
5. Overbaugh KJ. Acute coronary syndrome. AJN. 2009;109(5):42-52.

6. WHO. Cardiovascular risk factor trends and potential for reducing coronary heart disease mortality in the United States of America. 2013 (diunduh 24 Maret 2013). Tersedia dari: URL: HYPERLINK

http://www.who.int/bulletin/volumes/88/2/08057885/en/.

7. National Institutes of Health, National Heart, Lung, and Blood Intitute. The seventh report of the joint national committee on prevention, detection, evaluation, and treatment of high blood pressure (JNC VII). 2004 (diunduh 19 Februari; 2013). Tersedia dari: URL: HYPERLINK www.nhlbi.nih.gov/guidelines/hypertension/jnc7fu II.

8. McGill HC, McMahan CA. Overview. Dalam: Valestine F, Eric J, Elizabeth GN, editor. Atherothrombus and coronary artery disease. Lippincot Williams and Wilkins; 2005. hlm.23.

9. Yogiantoro M. Hipertensi esensial. Dalam: Aru W. Sudoyo, editor. Buku Ajar IImu Penyakit Dalam Jllid III. Edisi ke-4. Jakarta: Pusat Penerbit Departemen FK UI; 2006. hlm.1079.

10. Kaplan NM. Kaplan'sclinical hypertension. Lippincott Williams and Wilkins; 2010.

11. Basile JN. Treatment of elderly hypertensive: Systolic hypertensive. Dalam: Izzo JL, Domenic AS, Henry RB, editor. Hypertension Primer. Lippincott Williams and Wilkins; 2008. hlm. 4858.

12. Kementerian Kesehatan Republik Indonesia Riset kesehatan dasar (Riskesdas) 2007; 2008.

13. Dinas Kesehatan Kota Padang. Laporan tahunan tahun 2009. Edisi 2010; 2010.

14. Ali WM, Al Habib KF, Hersi A, Asaad N Sulaiman K, Al Shiek Ali A, et al. In-hospital complications and 1-year outcome of acute coronary syndrome in patients with hypertension. Eastern Mediterranean Health Journal. 2012; 18(9):902-10.

15. Anwar TB. Faktor risiko penyakit jantung koroner. 2004 (diunduh 8 Juli 2013). Tersedia dari: URL: HYPERLINK library.usu.ac.id/download/fk/gizibahri4.pdf

16. Abidin Z. Faktor risiko penyakit jantung koroner pada pasien rawat inap cardiovaskuler care unit (CVCU) cardiac centre RSUP DR. Wahidin Sudirohusodo Makassar periode Januari-Juli 2008 (skripsi): Universitas Hasanuddin; 2008.

17. Van Den Hoogen PCW, Feskens EJM, Nagelkerke, NJD, Menotti A, Nissinen A, Kromhout D. The relation between blood pressure and mortality due to coronary heart disease among men in different parts of the world. The New England Journal of Medicine. 2006; 342(1): 1-8.

18. Syatria A. Pengaruh olahraga terprogram terhadap tekanan darah pada mahasiswa fakultas kedokteran Universitas Diponegoro yang mengikuti ekstrakurikuler basket. 2006 (diunduh 9 September 2013). Tersedia dari: URL: HYPERLINK

http://eprints.undip.ac.id/20415/1/Arsdiani.pdf.

19. Sugiharto A. Faktor-faktor risiko hipertensi grade II pada masyarakat (studi kasus di kabupaten Karanganyar) (skripsi): Universitas Diponegoro; 2007. 
20. Irza S. Analisis faktor risiko hipertensi pada masyarakat nagari Bungo Tanjung, Sumatera Barat (skripsi): Universitas Sumatera Utara; 2009.

21. Zuriati A. Pengaruh teknik relaksasi otot progresif terhadap penurunan tekanan darah sistolik pada lansia dengan hipertensi diwilayah kerja puskesmas Air Tawar kelurahan Air Tawar Barat Padang 2010 (skripsi). Universitas Andalas; 2010.

22. Ismantri F. Prevalensi penderita penyakit jantung koroner yang menjalani intervensi koroner perkutan di Rumah Sakit Binawaluya tahun 20082009 (skripsi). Universitas Islam Negeri Syarif Hidayatullah; 2009. 